\title{
Selection and population genetic structure of the barnacle Semibalanus balanoides in the northwest Atlantic and Gulf of St. Lawrence*
}

\author{
Eric R. Holm**, Edwin Bourget \\ GIROQ, Département de Biologie, Université Laval, Ste-Foy, Québec, Canada G1K 7P4
}

\begin{abstract}
It has been proposed that population genetic structure at the mannose-6-phosphate isomerase (Mpi) locus in the barnacle Semibalanus balanoides (L.) could be due to selection by ice scour acting through variation in larval settlement behavior. Homogeneity of Mpi allele frequencies for barnacles within the Gulf of St. Lawrence could be maintained by a combination of selection and limited gene flow from populations of $S$. balanoides on the Atlantic coast of Canada south of the Cabot Strait. We sampled $S$. balanoides from 19 sites in Greenland and Baffin Island, the Gulf of St. Lawrence, and on the Atlantic coasts of Nova Scotia and New Brunswick, Canada, in order to test these hypotheses. Presumptive genetic variation at 2 enzyme loci, Mpi and glucose-6-phosphate isomerase (Gpi), was quantified by isoelectric focusing. All populations were in Hardy-Weinberg equilibrium, and no linkage disequilibrium between loci was observed. We found significant spatial variation in allele frequencies at both loci. In particular, $S$. balanoides populations within the Gulf of St. Lawrence were not genetically homogeneous at either locus. A discontinuity in allele frequencies at both the Gpi and Mpi loci occurred in the vicinity of the Miramichi estuary, in the southern Gulf. Comparisons of allele frequencies between barnacle recruits and adults suggested this population structure may have resulted from selection, in the case of Mpi, possibly associated with environmental temperature. Selection by ice scour does not appear to affect spatial variation in allele frequencies in the Gulf of St. Lawrence.
\end{abstract}

KEY WORDS: Semibalanus balanoides - Population genetics - Isoelectric focusing · Gpi · Mpi . Barnacle Selection

\section{INTRODUCTION}

Population genetic structure of sessile marine invertebrates can be affected by several processes, depending upon the life history of the species in question and the spatial scale of observation (see Grosberg 1991 for review). For species with long-lived planktonic larvae, population structure at large spatial scales (>10 to $100 \mathrm{~km}$ ) is a product of the interaction between selection and present and/or historical patterns of gene flow (e.g. Koehn et al. 1976, 1980, Hilbish 1985, Reeb \& Avise 1990, Karl \& Avise 1992).

\footnotetext{
- Contribution to the program of GIROQ (Groupe interuniversitaire de recherches océanographiques du Québec)

- Present address: Duke University Marine Laboratory.

Beaufort, North Carolina 28516, USA
}

The acorn barnacle Semibalanus balanoides (L.) is common in the intertidal zone of most rocky shores of the North Atlantic north of Cape Hatteras and northwestern Spain, and also occurs on the Pacific coast of southern Alaska (Flowerdew 1983b, Bourget et al. 1989). Larvae of $S$. balanoides are planktonic and complete development to the settlement stage in 3 to $7 \mathrm{wk}$ (Barnes \& Barnes 1958). Populations of $S$. balanoides from the northwestern Gulf of St. Lawrence (Capucins, Québec, Canada) are differentiated at the mannose-6phosphate isomerase (Mpi) locus from barnacles collected from Passamaquoddy Bay (St. Andrews, New Brunswick) on the Atlantic coast of Canada (Bourget et al. 1989, Martel 1990). Bourget et al. (1989) proposed that this population structure, as well as homogeneity of allele frequencies at the Mpi locus within the Gulf, could be maintained by selection by ice scour and limited gene flow. Selection would act through inter- 
population variation in larval settlement behavior. At Capucins (Gulf of St. Lawrence), cyprid larvae of $S$. balanoides settle mainly in crevices (Bourget 1988, Chabot \& Bourget 1988), where mortality due to ice scour is $<21 \%$, rather than on exposed surfaces where mortality from this source is $>90 \%$ (Bergeron \& Bourget 1986). At St. Andrews (Atlantic coast), larvae settle in crevices and on exposed surfaces, but prefer the latter (Bourget 1988, Chabot \& Bourget 1988). Patterns of surface circulation suggested that gene flow into the Gulf was mainly from more northern populations along the Labrador and, ultimately, Greenland coasts, as opposed to populations from the Atlantic coast south of the Cabot Strait (Bourget et al. 1989). S. balanoides on the northern coasts were presumed to be under similar selective pressures for cryptic settlement behavior as barnacles in the Gulf of St. Lawrence.

We analyzed samples of Semibalanus balanoides from 19 sites for variation at 2 enzyme loci (including $\mathrm{Mpi}$ ) in order to determine if barnacle populations from within the Gulf of St. Lawrence were genetically homogeneous, and, if any population genetic structure observed was consistent with gene flow into the Gulf from more northern regions and/or selection by ice scour or some correlated factor.

\section{MATERIALS AND METHODS}

Sample collection and processing. We sampled Semibalanus balanoides from 11 sites (Fig. 1) during 1990-91, including 2 sites each in Greenland (Nuuk, August $17 \& 19,1991$ ) and Baffin Island (Iqaluit, August 23, 1991), 3 sites in the Gulf of St. Lawrence (Capucins, November 20, 1990; Port Elgin, December 10, 1990; St. Augustin, August 1991), and 4 sites on the Atlantic coast of Nova Scotia and New Brunswick south of the Cabot Strait (St. Andrews, December 8, 1990; Queensland Beach, December 11, 1990; Port Morien, December 13, 1990; Ingonish, December 14, 1990).

Results from the 1990 Port Elgin sample suggested examination of additional populations within the southern Gulf of St. Lawrence was necessary. In 1992 Semibalanus balanoides were sampled from 9 sites (Fig. 2) including Port Daniel (June 21), Port Elgin (June 23), Pictou (June 24), Port Hood (June 25), Cheticamp (June 26), Shediac (June 27), Shippegan (October 27), Cap Lumière (October 28) and Burnt Church (November 1). We chose these sites to span 2 areas of strong tidal mixing (Shediac and Pictouj corresponding to locations where herring larvae are retained (Iles \& Sinclair 1982), and 2 cyclonic eddies (Cap Lumière and Port Hood; Lauzier 1965). These oceanographic features could potentially affect barnacle population structure by restricting dispersal of larvae.

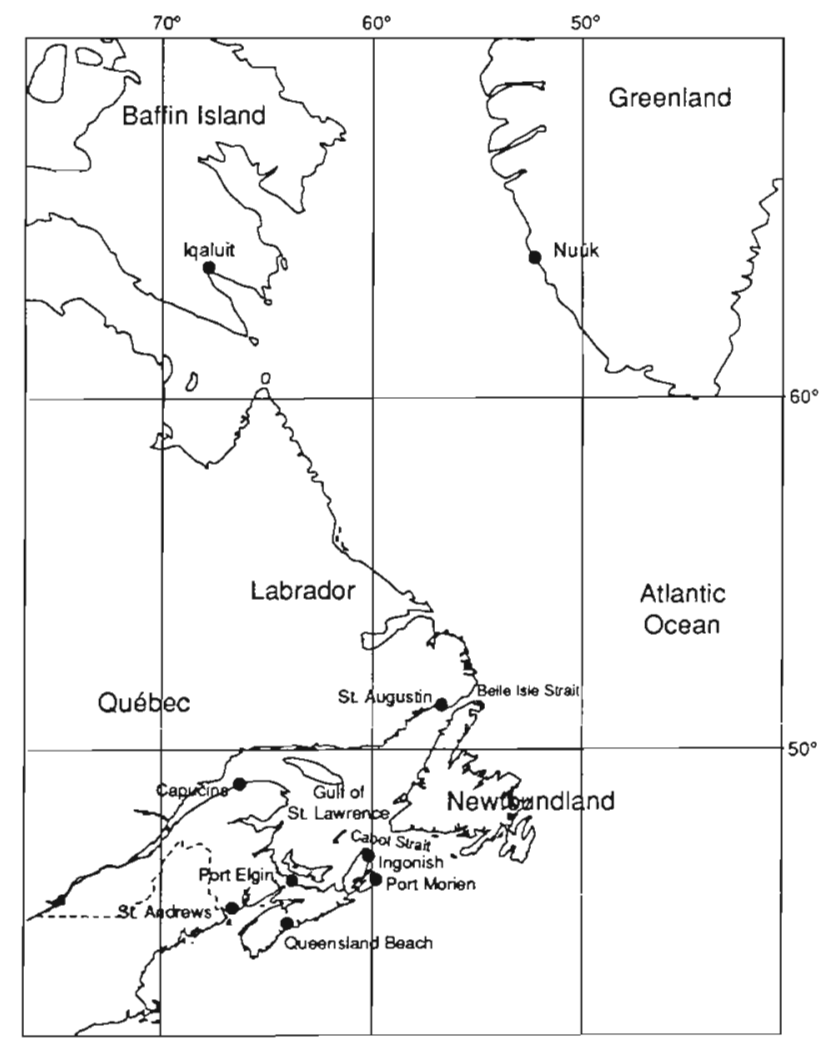

Fig. 1. Sites from which Semibalanus balanoides were collected in 1990-91. Barnacles were sampled from 2 sites at Nuuk and Iqaluit. At each site $S$. balanoides were collected haphazardly from the middle to lower part of the barnacle's intertidal distribution. Capucins and St. Andrews are the same locations sampled by Martel in 1988 (Bourget et al. 1989, Martel 1990)

At each site (except Burnt Church) cobbles or fragments of outcroppings supporting Semibalanus balanoides were collected haphazardly from the middle to lower part of the barnacle's intertidal distribution, and shipped to Université Laval for processing. In the laboratory, live adult barnacles, with shell, were removed from the rock, frozen in liquid nitrogen, and stored at $-70^{\circ} \mathrm{C}$ until homogenizing. At Burnt Church, barnacles were frozen on dry ice in the field before shipping to the laboratory for storage and processing. The barnacle prosoma was removed from the shell, weighed, and homogenized in grinding buffer $\left(8.33 \mathrm{ml} \mathrm{g}^{-1} \mathrm{sam}\right.$ ple; $50 \mathrm{mM}$ Tris-HCl, $1 \mathrm{mM} \mathrm{MgCl}, 1 \mathrm{mM} \mathrm{DTT,} 50 \%$ $\mathrm{v} / \mathrm{v}$ glycerol, adjusted to $\mathrm{pH}$ 7.5). Homogenized samples were stored at $-20^{\circ} \mathrm{C}$ until electrophoresis.

We found cobbles supporting barnacle recruits $<1$ to 3 mo old) at several of the sites sampled during June 1992. We left these recruits in place and froze the cobbles in $\mathrm{a}-70^{\circ} \mathrm{C}$ freezer. Later, individual recruits were removed from the cobbles with a dissecting probe, and homogenized in $3.5 \mu \mathrm{l}$ of grinding buffer. 


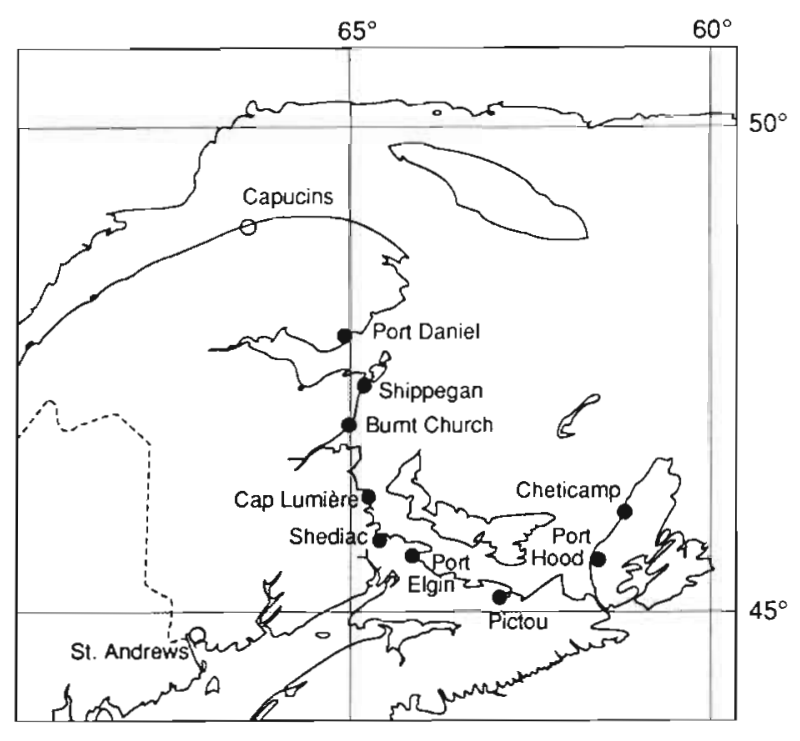

Fig. 2. Sites (•) from which Semibalanus balanoides were sampled in 1992. At each site $S$. balanoides were collected haphazardly from the middle to lower part of the barnacle's intertidal distribution. Capucins and St. Andrews (O) are locations sampled by Martel in 1988 (Bourget et al. 1989, Martel 1990) and resampled by us in 1990

Electrophoresis - isoelectric focusing. We resolved presumptive genetic variation at 2 enzyme loci, $\mathrm{Mpi}$ (EC 5.3.1.8) and glucose-6-phosphate isomerase (Gpi, EC 5.3.1.9), by isoelectric focusing of polyacrylamide gels. The Mpi and Gpi loci are strongly polymorphic in Semibalanus balanoides, and allele frequencies often exhibit substantial geographic variation (e.g. Flowerdew 1983a, b, Bourget et al. 1989, Martel 1990). Gels were $124 \times 258 \times 0.3 \mathrm{~mm}$, and consisted of $1.7 \mathrm{ml} 30 \%$ $\mathrm{w} / \mathrm{v}$ acrylamide $+1.6 \% \mathrm{w} / \mathrm{v}$ bis-acrylamide, $2 \mathrm{ml} 50 \%$

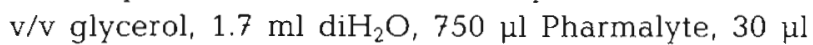
$0.5 \%$ DTT, $7.5 \mu \mathrm{l}$ TEMED, and $75 \mu \mathrm{ll} 10 \%$ ammonium persulfate. For Gpi, $750 \mu \mathrm{l}$ of pH 5-6 Pharmalyte was added, and for Mpi $375 \mu$ l each of $\mathrm{pH} \mathrm{2.5-5}$ and pH 5-6 Pharmalyte. For both gels DL-glutamic acid $(0.04 \mathrm{M})$ served as the anode electrolyte, and $0.1 \mathrm{M}$ $\mathrm{NaOH}$ the cathode electrolyte. Gels were prefocused for $5 \mathrm{~min}$ at $5 \mathrm{~W}$ before application of samples. For Gpi, $2.0 \mathrm{\mu l}$ of sample extract were applied at the anode; $M p i$ gels were loaded with $3.5 \mu \mathrm{l}$ of sample at the cathode. Gpi gels were focused for $10 \mathrm{~min}$ at 5,10 , and $15 \mathrm{~W}$, then for $20 \mathrm{~min}$ at $20 \mathrm{~W}$. Mpi gels were focused for $40 \mathrm{~min}$ at $5 \mathrm{~W}$, then $40 \mathrm{~min}$ at $10 \mathrm{~W}$. Gels were stained following Martel (1990). For Gpi the staining solution

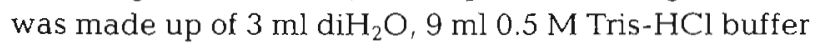
$(\mathrm{pH} 8), 0.6 \mathrm{ml} 0.5 \mathrm{M} \mathrm{MgCl}_{2}, 0.6 \mathrm{ml} 50 \mathrm{mM}$-fructose6-phosphate, $0.3 \mathrm{ml} 15 \mathrm{mM}$ NAD, $0.3 \mathrm{ml} 30 \mathrm{mM}$ NADP, 4.2 units glucose-6-phosphate dehydrogenase, $0.6 \mathrm{ml}$ $15 \mathrm{mM}$ MTT, $0.6 \mathrm{ml} 5 \mathrm{mM}$ PMS, and $15 \mathrm{ml}$ of $2 \% \mathrm{w} / \mathrm{v}$

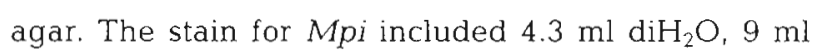
$0.5 \mathrm{M}$ Tris- $\mathrm{HCl}$ buffer ( $\mathrm{pH} 8), 0.3 \mathrm{ml} 50 \mathrm{mM} \mathrm{D-}$ mannose-6-phosphate, $0.18 \mathrm{ml} 30 \mathrm{mM} \mathrm{NADP}, 4.2$ units glucose-6-phosphate dehydrogenase, 30 units phosphoglucose isomerase, $0.6 \mathrm{ml} 15 \mathrm{mM}$ MTT, $0.6 \mathrm{ml}$ $5 \mathrm{mM}$ PMS, and $15 \mathrm{ml}$ of $2 \% \mathrm{w} / \mathrm{v}$ agar. Alleles were designated according to their distance from the cathode, with the closest band as allele 1. All samples were run against controls of known genotype.

Data analysis. We tested for deviations of genotype frequencies from Hardy-Weinberg equilibrium, and for associations among alleles at the Mpi and Gpi loci, using the disequilibrium coefficient approach of Weir (1990). Significant disequilibrium coefficients were identified using the sequentially rejective Bonferroni procedure (Holm 1979, Rice 1989) to correct for multiple tests. We used G-tests of independence (Sokal \& Rohlf 1981) to test for variation in allele frequencies among sites or between adults and recruits within a site. Confidence intervals for allele frequencies were calculated following Weir (1990).

\section{RESULTS}

Isoelectric focusing revealed 4 alleles at each locus, 2 common and 2 rare. To ensure that all expected cell frequencies were $>5$ (Sokal \& Rohlf 1981), rare alleles were pooled with alleles of the closest mobility before analysis of frequencies by $G$-test. All populations were in Hardy-Weinberg equilibrium at both loci, and there was no evidence of significant linkage disequilibrium between the loci. Banding patterns were consistent with previously reported (Murphy et al. 1990) quaternary structures for GPI and MPI.

As 2 common alleles accounted for 93 to $100 \%$ of all alleles observed at both loci, population structure could be described by frequencies of 1 common allele at each locus. Our discussion of spatial variation focuses on the common alleles $G p i^{3}$ and $M p i^{2}$.

\section{Population genetic structure - 1990-91 samples}

We observed significant variation in allele frequencies at both loci among the 11 sites sampled in 1990-91 (Table 1; Gpi: $\mathrm{G}=101.72, \mathrm{df}=10, \mathrm{p}<0.0001 ; \mathrm{Mpi}$ : $G=96.62, \mathrm{df}=10, \mathrm{p}<0.0001)$. The 4 far north samples at Nuuk and Iqaluit, and 2 samples from the northern Gulf of St. Lawrence (Capucins and St. Augustin), exhibited low (0.191 to 0.273 ) frequencies of $\mathrm{Mpi}^{2}$ (Table 1, Fig. 3). Frequencies of this allele on the Atlantic coast were higher, ranging from 0.395 at Queensland Beach to 0.472 at Ingonish. Allele frequencies at Port Elgin, in the southern Gulf of St. 
Table 1. Semibalanus balanoides. Allele frequencies at the Gpi and Mpiloci for barnacles collected in 1990-91 and 1992. Alleles were labeled according to their distance from the cathode, with the closest band as allele $1.95 \%$ confidence intervals for each frequency are given in parentheses. $\mathrm{n}$ : sample sizes for the Gpi and Mpi loci, respectively

\begin{tabular}{|c|c|c|c|c|c|c|c|}
\hline Site & $\mathrm{n}$ & $G p i^{1}$ & $G p i^{2}$ & $G p i^{3}$ & $M p i^{1}$ & $M p i^{2}$ & $\mathrm{Mpi}^{3}$ \\
\hline \multicolumn{8}{|c|}{ 1990-91 samples } \\
\hline Nuuk E & 96,90 & & $\begin{array}{c}0.505 \\
(0.435-0.575)\end{array}$ & $\begin{array}{c}0.495 \\
(0.425-0.565)\end{array}$ & $\begin{array}{c}0.011 \\
(0.000-0.026)\end{array}$ & $\begin{array}{c}0.228 \\
(0.166-0.290)\end{array}$ & $\begin{array}{c}0.761 \\
(0.699-0.823)\end{array}$ \\
\hline Nuuk P & 76,74 & & $\begin{array}{c}0.487 \\
(0.397-0.576)\end{array}$ & $\begin{array}{c}0.513 \\
(0.424-0.602)\end{array}$ & $\begin{array}{c}0.014 \\
(0.000-0.032)\end{array}$ & $\begin{array}{c}0.257 \\
(0.189-0.325)\end{array}$ & $\begin{array}{c}0.730 \\
(0.659-0.800)\end{array}$ \\
\hline Iqaluit $E$ & 93,88 & & $\begin{array}{c}0.608 \\
(0.535-0.680)\end{array}$ & $\begin{array}{c}0.392 \\
(0.320-0.465)\end{array}$ & $\begin{array}{c}0.006 \\
(0.000-0.017)\end{array}$ & $\begin{array}{c}0.273 \\
(0.208-0.337)\end{array}$ & $\begin{array}{c}0.722 \\
(0.657-0.786)\end{array}$ \\
\hline Iqaluit $P$ & 73,76 & & $\begin{array}{c}0.534 \\
(0.449-0.620)\end{array}$ & $\begin{array}{c}0.466 \\
(0.380-0.551)\end{array}$ & $\begin{array}{c}0.013 \\
(0.000-0.031)\end{array}$ & $\begin{array}{c}0.191 \\
(0.130-0.251)\end{array}$ & $\begin{array}{c}0.796 \\
(0.732-0.860)\end{array}$ \\
\hline Saint Augustin & 97,90 & & $\begin{array}{c}0.732 \\
(0.671-0.792)\end{array}$ & $\begin{array}{c}0.268 \\
(0.207-0.329)\end{array}$ & $\begin{array}{c}0.006 \\
(0.000-0.016)\end{array}$ & $\begin{array}{c}0.206 \\
(0.153-0.259)\end{array}$ & $\begin{array}{c}0.789 \\
(0.733-0.844)\end{array}$ \\
\hline Capucins & 90,90 & $\begin{array}{c}0.006 \\
(0.000-0.016)\end{array}$ & $\begin{array}{c}0.806 \\
(0.753-0.858)\end{array}$ & $\begin{array}{c}0.189 \\
(0.137-0.241)\end{array}$ & $\begin{array}{c}0.017 \\
(0.000-0.035)\end{array}$ & $\begin{array}{c}0.272 \\
(0.205-0.340)\end{array}$ & $\begin{array}{c}0.711 \\
(0.642-0.780)\end{array}$ \\
\hline Port Eigin & $92,7 \overline{7}$ & & $\begin{array}{c}0.522 \\
(0.454-0.589)\end{array}$ & $\begin{array}{c}0.478 \\
(0.411-0.546)\end{array}$ & $\begin{array}{c}0.006 \\
(0.000-0.019)\end{array}$ & $\begin{array}{c}0.539 \\
(0.463-0.615)\end{array}$ & $\begin{array}{c}0.454 \\
(0.378-0.531)\end{array}$ \\
\hline Ingonish & 91,89 & & $\begin{array}{c}0.615 \\
(0.551-0.680)\end{array}$ & $\begin{array}{c}0.385 \\
(0.320-0.449)\end{array}$ & & $\begin{array}{c}0.472 \\
(0.407-0.537)\end{array}$ & $\begin{array}{c}0.528 \\
(0.463-0.593)\end{array}$ \\
\hline Port Morien & 91,79 & & $\begin{array}{c}0.632 \\
(0.564-0.700)\end{array}$ & $\begin{array}{c}0.368 \\
(0.300-0.436)\end{array}$ & & $\begin{array}{c}0.424 \\
(0.343-0.505)\end{array}$ & $\begin{array}{c}0.576 \\
(0.495-0.656)\end{array}$ \\
\hline $\begin{array}{l}\text { Queensland } \\
\text { Beach }\end{array}$ & 95,86 & & $\begin{array}{c}0.653 \\
(0.587-0.718)\end{array}$ & $\begin{array}{c}0.347 \\
(0.282-0.413)\end{array}$ & & $\begin{array}{c}0.395 \\
(0.320-0.471)\end{array}$ & $\begin{array}{c}0.605 \\
(0.529-0.681)\end{array}$ \\
\hline Saint Andrews & 91,85 & $\begin{array}{c}0.006 \\
(0.000-0.016)\end{array}$ & $\begin{array}{c}0.791 \\
(0.728-0.854)\end{array}$ & $\begin{array}{c}0.203 \\
(0.141-0.266)\end{array}$ & & $\begin{array}{c}0.412 \\
(0.337-0.487)\end{array}$ & $\begin{array}{c}0.588 \\
(0.513-0.663)\end{array}$ \\
\hline \multicolumn{8}{|l|}{1992 samples } \\
\hline Port Daniel & 94,98 & & $\begin{array}{c}0.707 \\
(0.642-0.772)\end{array}$ & $\begin{array}{c}0.293 \\
(0.228-0.358)\end{array}$ & $\begin{array}{c}0.031 \\
(0.007-0.055)\end{array}$ & $\begin{array}{c}0.270 \\
(0.208-0.332)\end{array}$ & $\begin{array}{c}0.699 \\
(0.636-0.762)\end{array}$ \\
\hline Shippegan & 92,98 & & $\begin{array}{c}0.761 \\
(0.708-0.814)\end{array}$ & $\begin{array}{c}0.239 \\
(0.186-0.292)\end{array}$ & $\begin{array}{c}0.005 \\
(0.000-0.015)\end{array}$ & $\begin{array}{c}0.250 \\
(0.193-0.307)\end{array}$ & $\begin{array}{c}0.745 \\
(0.688-0.802)\end{array}$ \\
\hline Burnt Church & 94,92 & & $\begin{array}{c}0.691 \\
(0.630-0.752)\end{array}$ & $\begin{array}{c}0.309 \\
(0.248-0.370)\end{array}$ & $\begin{array}{c}0.011 \\
(0.000-0.026)\end{array}$ & $\begin{array}{c}0.272 \\
(0.209-0.335)\end{array}$ & $\begin{array}{c}0.717 \\
(0.652-0.782)\end{array}$ \\
\hline Cap Lumière & 94,91 & & $\begin{array}{c}0.553 \\
(0.480-0.626)\end{array}$ & $\begin{array}{c}0.447 \\
(0.374-0.520)\end{array}$ & & $\begin{array}{c}0.484 \\
(0.409-0.559)\end{array}$ & $\begin{array}{c}0.516 \\
(0.441-0.591)\end{array}$ \\
\hline Shediac & 94,94 & & $\begin{array}{c}0.564 \\
(0.496-0.632)\end{array}$ & $\begin{array}{c}0.436 \\
(0.368-0.504)\end{array}$ & & $\begin{array}{c}0.495 \\
(0.421-0.569)\end{array}$ & $\begin{array}{c}0.505 \\
(0.430-0.580)\end{array}$ \\
\hline Port Elgin & 96,93 & & $\begin{array}{c}0.573 \\
(0.505-0.641)\end{array}$ & $\begin{array}{c}0.427 \\
(0.359-0.495)\end{array}$ & & $\begin{array}{c}0.495 \\
(0.426-0.564)\end{array}$ & $\begin{array}{c}0.505 \\
(0.436-0.574)\end{array}$ \\
\hline Pictou & 93,98 & $\begin{array}{c}0.005 \\
(0.000-0.015)\end{array}$ & $\begin{array}{c}0.602 \\
(0.530-0.674)\end{array}$ & $\begin{array}{c}0.392 \\
(0.321-0.463)\end{array}$ & $\begin{array}{c}0.010 \\
(0.000-0.024)\end{array}$ & $\begin{array}{c}0.444 \\
(0.376-0.512)\end{array}$ & $\begin{array}{c}0.546 \\
(0.477-0.615)\end{array}$ \\
\hline Port Hood & 94,91 & & $\begin{array}{c}0.527 \\
(0.453-0.601)\end{array}$ & $\begin{array}{c}0.473 \\
(0.399-0.547)\end{array}$ & $\begin{array}{c}0.005 \\
(0.000-0.015)\end{array}$ & $\begin{array}{c}0.456 \\
(0.382-0.531)\end{array}$ & $\begin{array}{c}0.538 \\
(0.463-0.613)\end{array}$ \\
\hline Cheticamp & 88,81 & & $\begin{array}{c}0.557 \\
(0.495-0.619)\end{array}$ & $\begin{array}{c}0.443 \\
(0.381-0.505)\end{array}$ & $\begin{array}{c}0.006 \\
(0.000-0.018)\end{array}$ & $\begin{array}{c}0.469 \\
(0.390-0.548)\end{array}$ & $\begin{array}{c}0.525 \\
(0.447-0.603)\end{array}$ \\
\hline
\end{tabular}

Lawrence, differed strongly from the other Gulf samples. At this location the frequency of $\mathrm{Mpi}^{2}(0.539)$ was higher than that observed at Capucins and St. Augustin, and comparable to values for the Atlantic coast sites

Geographic variation in allele frequencies at the Gpi locus was complex. Gpi ${ }^{3}$ decreased in frequency from the far north sites to the northwestern Gulf of St.
Lawrence at Capucins, increased between Capucins and Port Elgin to values similar to those found in Greenland and Baffin Island samples, then decreased again moving out of the Gulf and south along the Atlantic coast of Nova Scotia and New Brunswick (Table 1, Fig. 3). As with $M p i^{2}$, frequency of $G p i^{3}$ at Port Elgin differed from that of the other 2 Gulf locations. 


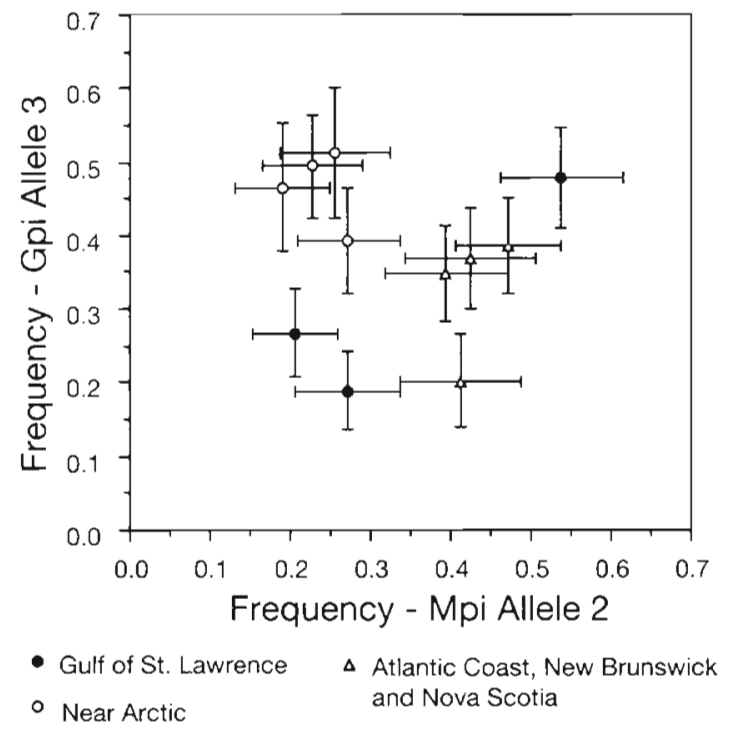

Fig. 3. Semibalanus balanoides. Geographic variation in frequencies of $G \mathrm{pi}^{3}$ and $M p i^{2}$ for barnacles collected in 199091 Error bars represent $95 \%$ confidence intervals for frequencies at each site. Variation at both loci was significant

(Gpi: $G=101.72, \mathrm{p}<0.0001 ; M p i: G=96.62, \mathrm{p}<0.0001$ )

\section{Population genetic structure - southern Gulf of St. Lawrence}

The results from Port Elgin suggested that Semibalanus balanoides populations within the Gulf of St. Lawrence were not genetically homogeneous at either of the loci. In 1992 we sampled barnacles at additional sites in the southern Gulf (Fig. 2) in order to determine if the allele frequencies seen at Port Elgin were characteristic of this portion of the Gulf of St. Lawrence, and if any population structure observed corresponded to oceanographic features which could affect larval dispersal (see 'Sample collection and processing' above).

Gpi and Mpi showed significant geographic variation in allele frequencies within the southern Gulf (Table 1; Gpi: $G=44.56, \mathrm{df}=8, \mathrm{p}<0.0001$; $M p i: G=$ 64.79 , df $=8, p<0.0001$ ). Allele frequencies at both Ioci clearly divided the samples into 2 groups (Fig. 4). One group, comprising samples from Port Daniel, Shippegan, and Burnt Church, was characterized by low (0.239 to 0.309) frequencies of $\mathrm{Gpi}^{3}$ and $\mathrm{Mpi}^{2}$ (Table 1), similar to barnacles collected in 1990-91 from Capucins and St. Augustin. At all other sites frequencies of $\mathrm{Cpi}^{3}$ and $\mathrm{Mpi}^{2}$ were higher (0.392 to 0.495; Table 1), comparable to values obtained for Port Elgin in 1990-91. The discontinuity in allele frequencies occurred over a distance of 50 to $100 \mathrm{~km}$ in the vicinity of the Miramichi estuary. Populations of Semibalanus

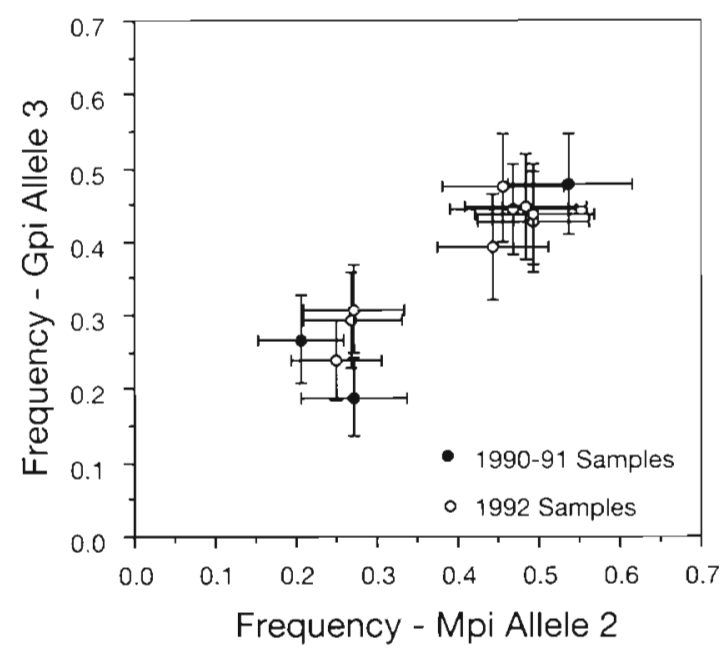

Fig. 4. Semibalanus balanoides. Geographic variation in frequencies of $\mathrm{Gpi}^{3}$ and $\mathrm{Mpi}^{2}$ for barnacles collected from the Gulf of St. Lawrence in 1990-91 and 1992. Error bars represent $95 \%$ confidence intervals for frequencies at each site. In 1992 variation at both loci was significant (Gpi: $G=44.56$, $\mathrm{p}<0.0001 ;$ Mpi: $G=64.79, \mathrm{p}<0.0001)$

balanoides north and west of the estuary had low frequencies of $\mathrm{Gpi}^{3}$ and $\mathrm{Mpi}^{2}$; south and east of the estuary frequency of these alleles increased (Fig. 5).

\section{Comparisons between recruits and adults}

We found large numbers of barnacle recruits at 4 locations in the southern Gulf of St. Lawrence, including 1 site (Port Daniel) northwest of the Miramichi estuary, and 3 sites (Shediac, Port Elgin, Pictou) southeast of the estuary. Allele frequencies at the Gpi locus did not differ significantly between recruits and adults at any of these sites. Gpi ${ }^{3}$ frequencies in recruits were low at Port Daniel and increased southeast of the Miramichi (Table 2, Fig. 5). Allele frequencies at the Mpi locus were similar in recruits and adults for samples from Port Daniel, Port Elgin and Pictou (Fig. 5). At Shediac, however, allele frequencies differed between these age classes $(G=5.572$, df $=1, p \leq 0.018)$. Frequency of $\mathrm{Mpi}^{2}$ in recruits from Shediac was lower than in adults, and intermediate between values observed for Semibalanus balanoides from the northwestern and southern Gulf (Table 2, Fig. 5).

\section{DISCUSSION}

Bourget et al. (1989, see also Martel 1990) observed significant variation at the Mpi locus between populations of Semibalanus balanoides from the northwest- 


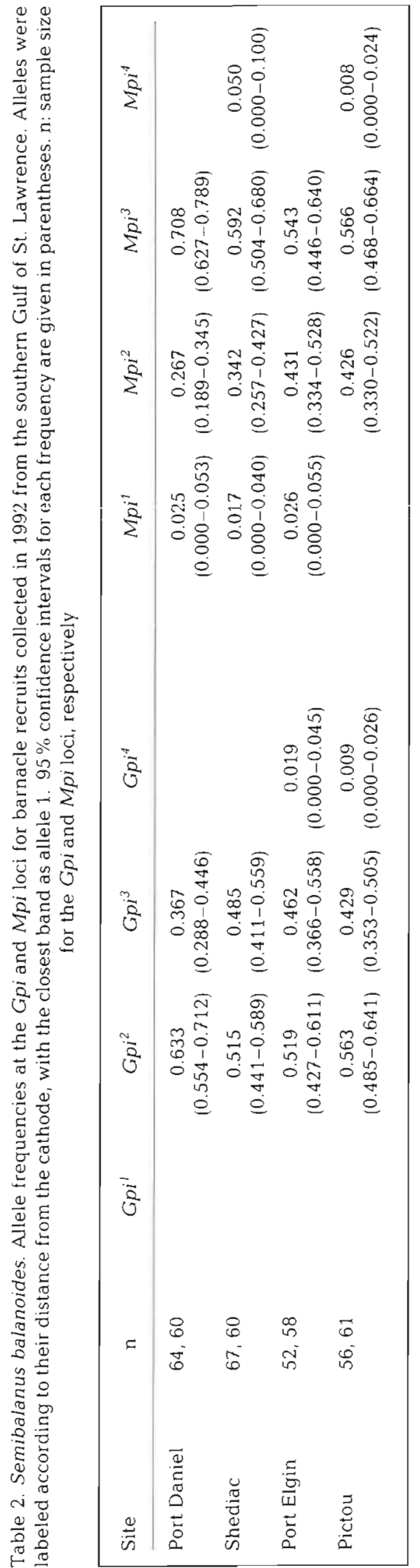

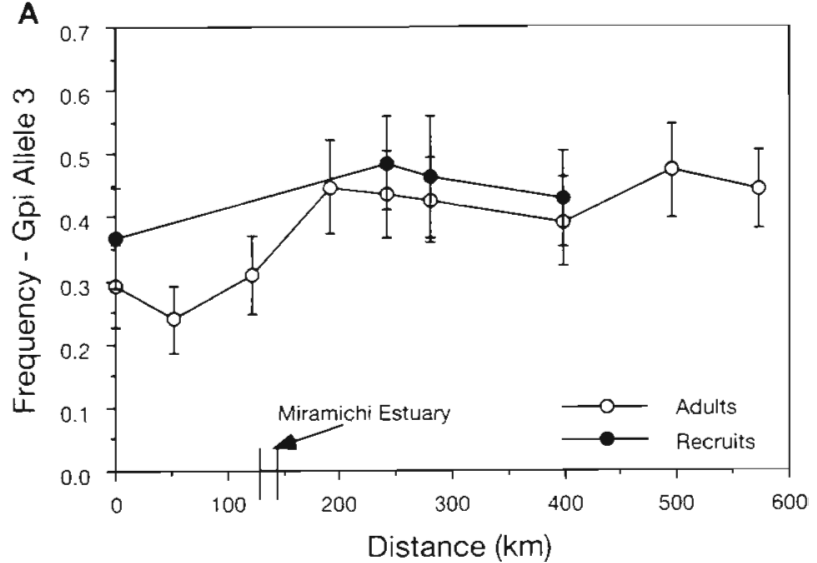

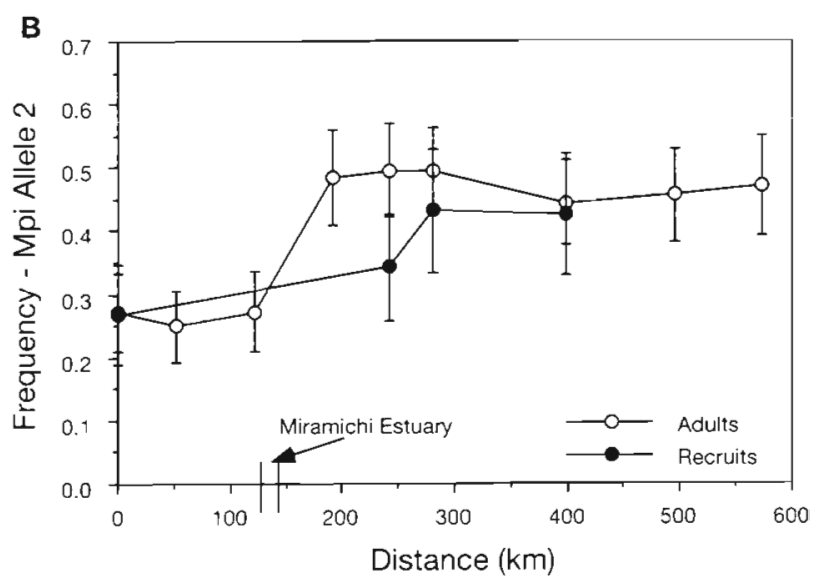

Fig. 5. Semibalanus balanoides. Change in frequency of (A) $G \mathrm{pi}^{3}$, and (B) $\mathrm{Mpi}^{2}$ with distance, starting with Port Daniel at $0 \mathrm{~km}$, for barnacles collected from the southern Gulf of St. Lawrence during 1992. Distances were estimated from 1:500000 scale maps as straight line distance between sites. Error bars represent $95 \%$ confidence intervals for allele frequencies

ern Gulf of St. Lawrence and the Atlantic coast of New Brunswick, and proposed that this differentiation could be due to selection by ice scour acting through settlement behavior. Furthermore, it was suggested that selection, combined with strong gene flow from barnacle populations to the north and limited dispersal of larvae into the Gulf from $S$. balanoides populations south of the Cabot Strait, could maintain genetic homogeneity at the Mpi locus among barnacle populations within the Gulf (Bourget et al. 1989). Our analysis clearly demonstrates that $S$. balanoides populations within the Gulf of St. Lawrence are not genetically homogeneous, and suggests that the processes generating spatial variation are probably not associated with selection by ice scour.

Frequencies of $\mathrm{Mpi}^{2}$ in the 4 samples of barnacles from the far north (Nuuk, Iqaluit) resembled frequen- 
cies in populations from the northern and western Gulf of St. Lawrence (St. Augustin, Capucins, Port Daniel, Shippegan, Burnt Church) and were lower than $\mathrm{Mpi}^{2}$ frequencies observed on the Atlantic coast of Nova Scotia and New Brunswick (Table 1, Fig. 3). These data are consistent with the hypotheses posed in Bourget et al. (1989). Samples collected at Port Elgin in 1990 and throughout the Northumberland Strait in 1992, however, point to the existence in the southern Gulf of large populations of Semibalanus balanoides with elevated $M p i^{2}$ frequencies more characteristic of samples from the Atlantic coast south of Cabot Strait (Table 1, Figs. $3 \& 4$ ). This result suggests: (1) selection by ice scour or some related factor does not cause the observed population structure at the Mpi locus, (2) selection by ice scour is spatially and/or temporally variable within the Gulf of St. Lawrence, or (3) the occurrence of dispersal of larvae, and subsequent gene flow, from southern Atlantic barnacle populations into the Gulf (Bourget \& Holm in press).

Several markers (and ideally, several classes of markers; Karl \& Avise 1992) are usually necessary to deduce the relative contributions of gene flow and selection to population genetic structure. Data for the Gpi locus are ambiguous as to gene flow between the Gulf of St. Lawrence and either far northern or Atlantic coast Semibalanus balanoides populations. If gene flow between far northern and Gulf populations was high, as proposed by Bourget et al. (1989), and variation at the Gpi locus neutral, then no differences in allele frequencies among samples from these locations should have been observed. Instead, we found a decrease in the frequency of $G p i^{3}$ from the far north sites to the northwestern Gulf, an increase in frequency of this allele in the southern Gulf, and a decrease in Gpi $i^{3}$ moving out of the Gulf south to St. Andrews on the Atlantic coast of New Brunswick (Table 1, Fig. 3).

We observed abrupt changes in allele frequencies at both the Gpi and Mpi loci over a distance of 50 to $100 \mathrm{~km}$ in the region of the Miramichi estuary (Table 1 , Figs. $4 \& 5$ ). The location of this discontinuity corresponded to a cyclonic eddy at the entrance to the Northumberland Strait (Lauzier 1965) which could have restricted larval dispersal (and consequently, reduced gene flow) between the western and southern Gulf. We compared allele frequencies in Semibalanus balanoides recruits ( $<3$ mo old) with frequencies in adults in order to make a preliminary determination of the importance of gene flow and selection in producing the discontinuity.

Circulation of surface waters in the Gulf of St. Lawrence is counterclockwise; in the southern Gulf flow is from the northwest to southeast (Koutitonsky \& Bugden 1991). Under these conditions larvae from the northwestern Gulf, characterized by lower frequencies of $\mathrm{Gpi}^{3}$ and $\mathrm{Mpi}^{2}$, should be transported into the Northumberland Strait. If dispersal were restricted, larvae from northwestern Semibalanus balanoides populations would not be transported into the southern Gulf, and allele frequencies in samples of newly settled barnacles, recruits, and adults would be similar. If dispersal were not restricted and selection produced the observed population genetic structure, frequencies of $G p i^{3}$ and $\mathrm{Mpi}^{2}$ in newly settled larvae and (depending on the timing of the selection event) recruits would be expected to be lower than in adults. Allele frequencies at the Gpi locus did not differ between recruits and adults for any of the 4 sites at which recruits were collected (Fig. 5A), suggesting either reduced gene flow and subsequent genetic drift, or selection on $G$ pi alleles during the planktonic phase of the life cycle or within 3 mo of settlement, caused the observed population structure. At the Mpi locus, however, recruits and adults differed in allele frequencies at Shediac, approximately $100 \mathrm{~km}$ southeast of the Miramichi estuary (Fig. 5B). Recruits at this site exhibited frequencies of $\mathrm{Mpi}^{2}$ between those observed in $S$. balanoides populations from the northwestern and southern Gulf of St. Lawrence, while frequencies in adult barnacles were representative of the southern Gulf. This result suggests that larvae from the northwestern Gulf disperse into the southern Gulf across the discontinuity in allele frequencies, and that differentiation at the 2 loci within the Gulf is due to selection, either directly on the loci or on loci in linkage disequilibrium with Gpi or Mpi. The timing of selection, and therefore probably also the agent generating selective pressures, differs for the 2 loci.

We stress that these conclusions should be regarded as preliminary, as they are based on a single significant comparison of measurements taken on individuals from different cohorts. Other processes may have generated the patterns we observed. For example, dispersal of larvae from the northwestern to southern Gulf may be temporally variable, but generally restricted. Our observations may represent an unusual case of transport of larvae between populations that have diverged by genetic drift. Quantification of changes in Gpi and Mpi allele frequencies with time in several cohorts of newly settled barnacles, replicated over multiple years, is necessary to test the selection hypothesis.

To summarize, Semibalanus balanoides populations within the Gulf of St. Lawrence are not genetically homogeneous, and population structure at both the Mpi and Gpi loci appears to be the result of selection. Additionally, within the southern Gulf high frequencies of $\mathrm{Mpi}^{2}$ are maintained relative to northern and western barnacle populations. Selection by ice scour 
would have been expected to maintain low frequencies of this allele (Bourget et al. 1989). As both loci apparently are under selection, no conclusions as to the relative importance of gene flow in this system can be drawn.

\section{Population genetic structure and environmental factors}

Associations between spatial variation in environmental factors and allele frequencies suggest potential causes of selection at enzyme loci. Population structure at the Gpi and Mpi loci has been related to characteristics of the environment in a number of species. Temperature appears to be an important agent of selection at the Gpi locus in sea anemones (Hoffmann 1981b), mussels (Hall 1985), amphipods (Patarnello \& Battaglia 1992), and fish (Van Beneden \& Powers 1989), and the kinetic properties of different allelic forms of GPI vary with temperature (Hoffmann 1981a, Hall 1985, Van Beneden \& Powers 1989, Zamer \& Hoffmann 1989). Shihab \& Heath (1987) found that selection for Gpi genotypes in a freshwater isopod was correlated with low oxygen concentration. McDonald (1987, 1991) associated population structure at the Mpi locus with exposure in 3 species of intertidal amphipods.

Using reciprocal transplants, Bertness \& Gaines (1993) showed that recruits of Semibalanus balanoides in Narragansett Bay (Rhode Island, USA) were under selection by temperature stress. In our barnacle samples there is no obvious relationship between population structure at the Gpi locus and environmental temperature. Surface water temperatures in the southern Gulf of St. Lawrence are higher than in other regions of the Gulf during much of the year, but especially in the summer (Bousfield \& Thomas 1975, Petrie 1990, Koutitonsky \& Bugden 1991), and the southern Gulf supports marine invertebrate species characteristic of the Atlantic coast from Cape Cod south (Bousfield \& Thomas 1975). S. balanoides populations from the southern Gulf of St. Lawrence, however, show allele frequencies at the Gi locus similar to populations from the far north (Nuuk, Iqaluit; Table 1), where temperatures are presumably much lower. Geographic variation at the Mpi locus may be consistent with selection by environmental temperature. Our samples can be divided into 2 groups on the basis of frequency of the $\mathrm{Mpi}^{2}$ allele (Bourget \& Holm in press). A 'northern' group, associated with cooler water temperatures and including barnacles from the far north sites and northern and western Gulf, is characterized by low 10.2 to 0.3) frequencies of $\mathrm{Mpi}^{2}$. A 'southern' group, including barnacles from the southern Gulf of St. Lawrence and Atlantic coasts of Nova Scotia and New Bruns- wick, is associated with warmer water temperatures and shows higher frequencies of $\mathrm{Mpi}^{2}(0.4$ to 0.5$)$.

Although the Burnt Church site occurs well within the region of higher surface water temperatures in the southern Gulf, the Semibalanus balanoides sample from this location exhibited low frequencies of $\mathrm{Mpi}^{2}$ $(0.272)$ representative of the 'northern' group. This could be an effect of gene flow between 'northern' and 'southern' barnacle populations. Asymmetrical (i.e. directional) gene flow can cause shifts in the position of allele frequency clines, in the direction of the gene flow (see Endler 1977 for review). Surface circulation in the Gulf of St. Lawrence (see above) should transport larvae from 'northern' populations of $S$. balanoides in the northwestern Gulf into the warmer waters of the southern Gulf, resulting in asymmetrical gene flow and shifting the discontinuity in $M p i$ allele frequencies into the region of higher water temperatures.

\section{Population genetic structure and geographic races of Semibalanus balanoides}

Crisp (1964, 1968) observed differences between European and North American populations of Semibalanus balanoides in the median date of fertilization and the development rate of embryos. These differences persisted in barnacles transplanted from Massachusetts to Wales (Crisp 1964) and from Wales to Newfoundland (Crisp 1968), suggesting the variation had a genetic component. On the basis of this evidence, Crisp (1964) proposed the existence of North American and European races of $S$. balanoides. Flowerdew $(1983 a, b)$ supported the division of $S$. balanoides into Pacific, North American (including Iceland), and European races, citing variation at the Gpi and $M p i$ loci.

Our analysis suggests that division of Semibalanus balanoides into races based on allele frequencies at the Gpi and Mpi loci is not correct. The range of allele frequencies we observed at both loci within the Gulf of St. Lawrence (and, in the southern Gulf, across a distance of 50 to $100 \mathrm{~km}$ ) spans the range reported by Flowerdew $(1983 \mathrm{a}, \mathrm{b})$ for barnacle populations from Europe, Canada, and the United States (Fig. 6A, B). This comparison does not require that our $G p i^{3}$ and $\mathrm{Mpi}^{2}$ are the same alleles as Flowerdew's $(1983 \mathrm{a}, \mathrm{b})$ $G i^{182}$ and $M p i^{100}$; we are comparing only the range in frequencies found for the common alleles. There is no reason to expect that geographic variation in a quantitative character such as (presumably) development rate should correspond to variation in allele frequencies at enzyme loci (e.g. Lewontin 1984). While differences in reproductive biology and development may indicate the existence of physiological races of $S$. bal- 


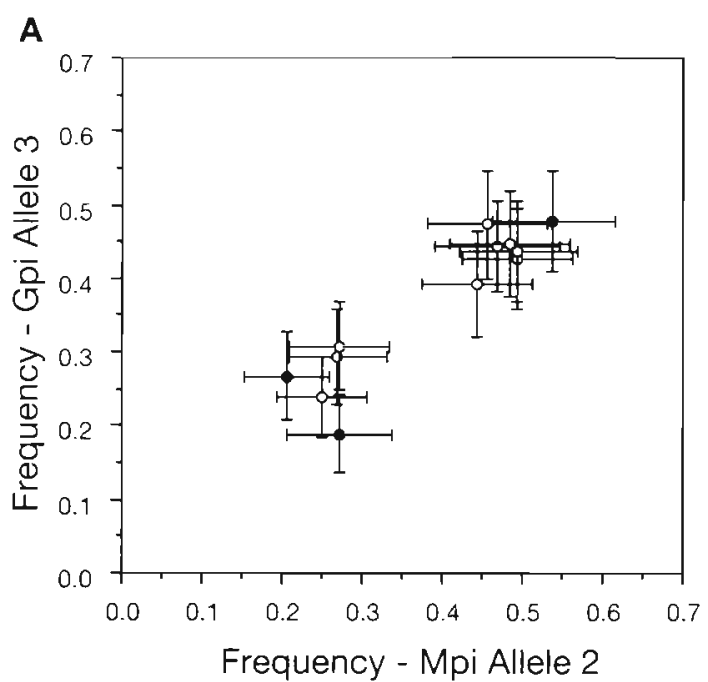

B

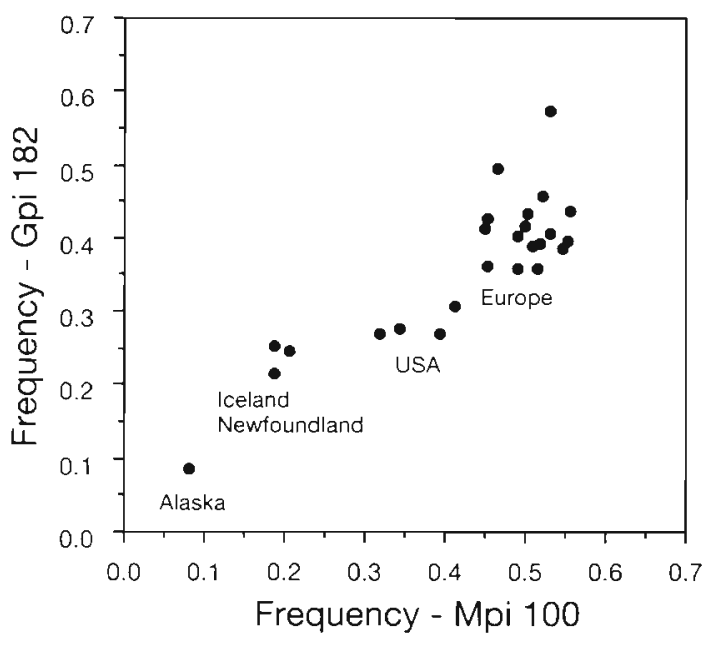

Fig. 6. Semibalanus balanoides. Geographic variation in allele frequencies at the Gpi and Mpi loci. (A) Barnacles collected from the Gulf of St. Lawrence in 1990-92, and (B) barnacle samples analyzed by Flowerdew $(1983 a$, b). Error bars in (A) represent $95 \%$ confidence interval

anoides at continental (>1000 km) spatial scales, our results from the Gulf of St. Lawrence strongly suggest that variation at the Gpi and Mpi loci is under the influence of processes acting over much smaller spatial scales.

Acknowledgements. We thank A. Buss of the Science Institute of the Northwest Territories of Canada and the Commission of Scientific Research in Greenland for granting permission to collect barnacles at Iqaluit and Nuuk, respectively. N. Cantin-Plante, C. Cyr, L. Lapointe, and M. Lecourt assisted with processing and analysis of samples. S. Gugg drafted Figs. 1 \& 2. A. Brown, M. Krause, D. Rittschof, and 2 anonymous reviewers provided valuable comments on earlier drafts of this manuscript. This research was supported by grants from NSERC and FCAR to E.B.

\section{LITERATURE CITED}

Barnes, H., Barnes, M. (1958). The rate of development of Balanus balanoides (L.) larvae. Limnol. Oceanogr. 3: 29-32

Bergeron, P., Bourget, E. (1986). Shore topography and spatial partitioning of crevice refuges by sessile epibenthos in an ice disturbed environment. Mar. Ecol. Prog. Ser. 28: 129-145

Bertnes5, M. D., Gaines, S. D. (1993). Larval dispersal and local adaptation in acorn barnacles. Evolution 47: 316-320

Bourget, E. (1988). Barnacle larval settlement: the perception of cues at different spatial scales. In: Chelazzi, G., Vannini, M. (eds.) Behavioral adaptation to intertidal life. Plenum, New York, p. 153-172

Bourget, E., Holm, E. (in press). Large scale population genetics of the barnacle Semibalanus balanoides L. in the Gulf of St. Lawrence and NW Atlantic. In: Dyer, K. R. (ed.) Changes in fluxes in estuaries: implications from science to management. Proceedings of ECSA Symposium 22, ECSA/ERF Joint Conference

Bourget, E., Martel, N., Lapointe, L., Bussières, D. (1989). Behavioural, morphological and genetic changes in some North Atlantic populations of the barnacle Semibalanus balanoides. In: Garbary, D. J., South, G. R. (eds.) Evolutionary biogeography of the marine algae of the North Atlantic. NATO ASI Series, Vol. G22. Springer-Verlag, Berlin, p. 87-106

Bousfield, E. L., Thomas, M. L. H. (1975). Postglacial changes in distribution of littoral marine invertebrates in the Canadian Atlantic region. Proc. Nova Scotia Inst. Sci. 27 (Suppl. 3): $47-60$

Chabot, R., Bourget, E. (1988). Influence of substratum heterogeneity and settled barnacle density on the settlement of cypris larvae. Mar. Biol. 97: 45-56

Crisp, D. J. (1964). Racial differences between North American and European forms of Balanus balanoides. J. mar. biol. Ass. U.K. 44: 33-45

Crisp, D. J. (1968). Differences between North American and European populations of Balanus balanoides revealed by transplantation. J. Fish. Res. Bd Can. 25: 2633-2641

Endler, J. A. (1977). Geographic variation, speciation, and clines. Princeton University Press, Princeton

Flowerdew, M. W. (1983a). Electrophoretic investigation of populations of the cirripede Balanus balanoides (L.) around the north Atlantic seaboard. Crustaceana 45 : $260-278$

Flowerdew, M. W. (1983b). The circumboreal barnacle Balanus balanoides (L.) and its subpopulations. In: Oxford, G. S., Rollinson, D. (eds.) Protein polymorphism: adaptive and taxonomic significance. Systematics Association Spec. Vol. 24. Academic Press, London, p. 75-84

Grosberg, R. K. (1991). Sperm-mediated gene flow and the genetic structure of a population of the colonial ascidian Botryllus schlosseri. Evolution 45: 130-142

Hall, J. G. (1985). Temperature-related kinetic differentiation of glucosephosphate isomerase alleloenzymes isolated from the blue mussel, Mytilus edulis. Biochem. Genet. 25; $705-728$

Hilbish, T J. (1985). Demographic and temporal structure of an allele frequency cline in the mussel Mytilus edulis. Mar. Biol. 86: 163-171

Hoffmann, R. J. (1981a). Evolutionary genetics of Metridium senile. I. kinetic differences in phosphoglucose isomerase allozymes. Biochem. Genet. 19: 129-144

Hoffmann, R. J. (1981b). Evolutionary genetics of Metridium senile. II, geographic patterns of allozyme variation. Biochem. Genet. 19: 145-154 
Holm, S. (1979). A simple sequentially rejective multiple test procedure. Scand. J. Statist. 6: 65-70

Iles, T. D., Sinclair, M. (1982). Atlantic herring: stock discreteness and abundance. Science 215: 627-633

Karl, S. A., Avise, J. C. (1992). Balancing selection at allozyme loci in oysters: implications from nuclear RFLPs. Science 256: $100-102$

Koehn, R. K., Milkman, R., Mitton, J. B. (1976). Population genetics of marine pelecypods. IV. Selection, migration and genetic differentiation in the blue mussel Mytilus edulis. Evolution 30: 2-32

Koehn, R. K., Newell, R. I. E., Immerman, F. (1980). Maintenance of an aminopeptidase allele frequency cline by natural selection. Proc. natl Acad. Sci. U.S.A. 77: 5385-5389

Koutitonsky, V. G., Bugden, G. L. (1991). The physical oceanography of the Gulf of St. Lawrence: a review with emphasis on the synoptic variability of the motion. In: Therriault, J.-C. (ed.) The Gulf of St. Lawrence: small ocean or big estuary. Can. Spec. Publ. Fish. Aquat. Sci. 113: $57-90$

Lauzier, L. M. (1965). Drift bottle observations in Northumberland Strait, Culf of St. Lawrence. J. Fish. Res. Bd Can. 22: $353-368$

Lewontin, R. C. (1984), Detecting population differences in quantitative characters as opposed to gene frequencies. Am. Nat. 123: 115-124

Martel, N. (1.990). Différenciation génétique des cirripèdes (Semibalanus balanoides) du golfe du Saint-Laurent et de la côte atlantique canadienne. M.Sc. thesis, Université Laval, Ste-Foy

McDonald, J. H. (1987). Repeated geographic variation at three enzyme loci in the amphipod Platorchestia platensis. Evolution 41: 438-441

McDonald, J. H. (1991). Contrasting amounts of geographical variation as evidence for direct selection: the $\mathrm{Mpi}$

This article was submitted to the editor and Pgm loci in eight crustacean species. Heredity 67 : $215-219$

Murphy, R. W., Sites, J. W., Jr., Buth, D. G., Haufler, C. H. (1990). Proteins I: isozyme electrophoresis. In: Hillis. D. M., Moritz, C. (eds.) Molecular systematics. Sinauer Associates, Sunderland, MA, p. 45-126

Patarnello, T., Battaglia, B. (1992). Glucosephosphate isomerase and fitness: effects of temperature on genotype dependent mortality and enzyme activity in two species of the genus Gammarus (Crustacea: Amphipoda). Evolution 46: $1568-1573$

Petrie, B. (1990). Monthly means of temperature, salinity and sigma-t for the Gulf of St. Lawrence. Can. Tech. Rep. Hydrogr. Ocean Sci. 126

Reeb, C. A., Avise, J. C. (1990). A genetic discontinuity in a continuously distributed species: mitochondrial DNA in the American oyster, Crassostrea virginica. Genetics 124: $397-406$

Rice, W. R. (1989). Analyzing tables of statistical tests. Evolution 43: 223-225

Shihab, A. F, Heath, D. J. (1987). Components of fitness and the PGI polymorphism in the freshwater isopod Asellus aquaticus (L.) 2. Zygotic selection. Heredity 58: 289-295

Sokal, R. R., Rohlf, F. J. (1981). Biometry. W. H. Freeman \& Co., San Fráncisco

Van Beneden, R. J., Powers, D. A. (1989). Structural and functional differentiation of two clinally distributed glucosephosphate isomerase allelic isozymes from the teleost Fundulus heteroclitus. Mol. Biol. Evol. 6: 155-170

Weir, B. S. (1990). Genetic data analysis. Sinauer Associates, Sunderland, MA

Zamer, W. E., Hoffmann, R. J. (1989). Allozymes of glucose-6phosphate isomerase differentially modulate pentoseshunt metabolism in the sea anemone Metridium senile. Proc. natl Acad. Sci. U.S.A. 86: 2737-2741

Manuscript first received: February 18, 1994

Revised version accepted: July 4, 1994 